\title{
The Role of Aristotelian Appeals in Influencing Consumer Behavior
}

\author{
Yog Raj Lamichhane \\ School of Business \\ Faculty of Management Studies, Pokhara University \\ lcyograj@gmail.com
}

\begin{abstract}
The purpose of this paper is to identify the effects of some representative print advertisements on consumer, relating to Aristotelian appeals- ethos, logos and pathos individually or simultaneously. How advertisers utilized this trinity to influence the behavior of consumers to use their products and services is the major concern of this study. For this, nine print advertisements which were published in two English newspapers of Nepal are studied. These adverts are conveniently taken from the Republica and The Himalayan Times of 15 and 16 February 2017. It accomplishes the intense assessment and yawning interpretation of the entire selected samples to expose the newspaper advertising behavior using content analysis. Languages of advertising are read between the lines. Used images and colors are also discussed relating to their symbolic meanings. Marketing strategies like free offer, buy one get one free, discounts, celebrity endorsement, expert opinion, sex appeals, etc are highly exercised to craft credibility, sentiment and reason to move audience and seeming common concepts and objects are transferred into highly desirable services and products. Maximum advertisers are so mindful to merge language, image and color according to their nature of product and service keeping literate audience in mind. So, the study notifies the consumers about how they are being influenced by Aristotelian appeals and equips advertisers with tool and process of influencing consumer behavior while making advertisement. Among this trinity of ethos, pathos and logos, emotion is observed almost unavoidable and the emotion is also contributive to make ethos and logos more effective. Nevertheless it seems as black sheep, but the appropriate amalgamation of ethos, pathos and logos appears successful.
\end{abstract}

Keywords: Appeals, Ethos, Pathos, Logos, Influence and Advertising.

\section{Introduction}

Advertising is a form of persuasive and nonpersonal communication which is generally paid to encourage products and services by means of diverse media. Though the first advertizing evidence was found dates back to 3000s BC. But, "the first advertisement in English went into print in 1472, in order to sell a prayer book. The profession of advertising begun in the United States in 1841" (Hayko, 2010, p.79). In advertising, persuasion has been immense ongoing mysteries of rhetoric and interrelated to various disciplines (Sloane, 2001). Advertisement is always expected to establish connectivity between communicators and receivers. These receivers as consumers are geographically scattered in different locations but the advertisement goes there through different mass media to manipulate them. There is regular encounter with different forms of advertising in numerous means of mass communication. The advertising is a communication to the largest number of people about the products and services of business houses. It bridges seller and consumer by creating positive or negative impression to different situations. Materialistic public are basically manipulated by

Journal of Development and Social Engineering

Volume 3 | Number 1 | December 2017, 65-78

ISSN 2382-5332 @ School of Development and Social Engineering, Pokhara University 
advertisement in manipulating people's strongest needs and greatest terror to persuade them to buy the favored goods and services in this capitalistic world (Kanner \& Soule, 2004). In this way, any market capitalizes everything and transfers people to consumer only.

Advertising, being a form of marketing communication, always persuades its consumers to use the products and services negatively or positively. "The manipulation in marketing has become an issue which accompanies the daily life of the consumers" (Danciu, 2014, p. 31). To make advertisement more persuasive, there exist the manipulative components as well as information which are primarily intended to communicate. The advertiser hits to influence the judgment of the consumer using various manipulative pictures and arguments. Advertisements are intended to draw attention, alter manner and to rule our behavior (Pollay, 1986). While evaluating the overall transforming process to consumer from business perspective, advertising includes extremely positive result which strengthens the economy despite the fact that in any advertising every person is converted to consumer (Kanner \& Soule, 2004). In the world of economy it is also defined as a catalyst for business (Coker \& One, 2012). In some cases related to social advertizing "a properly designed social advertisement could have important effects on disseminating useful information, changing or preventing unhealthy habits and adopting good practices in children" (Nicolini, Cassia, \& Bellotto, 2017, p.261).Thus, in this transforming process, advertisement creates positive effects by shaping and molding attitude of consumers to fortify economy. From the beginning of the rhetorical study, underlining philosophy of persuasion has been a focus of consideration (Sloane, 2001).

This relationship is further exposed with logical evidences in this paper connecting Aristotelian appeals as rhetoric to peruse the customer using content analysis. Severe analysis of advertising requires for the detection of the intended meaning and impacts which generally demands hardship. Inthis regard, Pollay argues "It is ironic that it is advertising's very omnipresence that contributes to its being taken for granted.
Like all environments its impact may be profound certainly beyond the obvious" (1986, p. 24).

\section{Summary of the Literature Review}

The impact of rational and emotional appeals on children's mind-set related to public service declaration that encouraged consumption fruits and vegetables has been studied by Nicolini, Cassia, \& Bellotto (2017) getting the free consent legally from the parents of 133 children. Using questionnaire and semi-structured focus group discussion children's perception of emotional and rational appeals in social advertisements was studied during school hours at a primary school in Verona, Italy. The results from the quantitative and qualitative phases met, reflecting that emotional and rational as key components in the fondness towards an advertisement even within them emotional part appeared to be the unsurpassed.

Mogaji (2016) has used content analysis to understand the types of advertisement appeals the banks are presenting to their consumers. Their perceptions of these creatively designed and emotionally appealing advertisements in UK banks' marketing communications based on newspaper advertisements were evaluated. Intending to expose marketing communication strategies, that content analysis of the advertisements of the UK based banks in the newspaper and semi-structured interviews of the banks associated to the implied connotation in those advertisements which were being successful means to shift the customers to the brands. Analyzing the content of nine UK National Newspapers over twelve months for about the emotional appeals offered by the banks in advertise revealed that UK banks used to employ emotional appeals much but there were distinction crosswise different bank groups .In addition, customers identify these emotional appeals presented by the banks in their advertisements, but it does not make any change of heart. They were unenthusiastic to discover other banks based on just advertisements. Rather than those things, they were more likely to depend on advice from family members and contacts. 
Slade (2002) explained that the newspapers and magazines sell readers to advertisers as commercial televisions sell their viewers to advertisers. It is applied in case of Web sites and in any form of mass Media in market. Using persuasive appeals, advertisements are intended to force people to assimilate a message, and then act on it. Slade studied about the nature of advertising stated that "usually it is a call to buy, but it might also be a call to vote in a particular way, or to change behavior or attitudes: to stop littering for instance" (2002, p. 157).

English, Sweetser, \& Ancu (2011) had examined of political talk on You Tube recruiting 233 participants from two Southeastern schools particularly in two states of UAS. The viral political videos in the month of the presidential election of 2008 were studied regarding persuasive appeals which were approximately $3 \mathrm{~min}$ long. However the study was focused only on Southwestern universities and it revealed ethos as number one credible appeal and that was followed by pathos and logos respectively and the promising finding was that users resist being influenced by emotion being honest to the source of message. To map political discourse of the social media involving during election campaigns SamuelAzran, Yarchi \& Wolfsfeld checked Israeli politicians' Aristotelian expression on Facebook and its response throughout the 2013 elections movement. It included 5 Israeli politicians on their Facebook walls during the election, and their popularity among their followers scrutinizing Aristotelian rhetorical strategies. The study concluded with that ethos was the most common rhetorical tactic they used. On the function frontage, pathosbased appeals involved the most likes (2015).

Jeon, Franke, Huhmann, \& Phelps (1999) examined the emotional and rational appeals in advertising for South Korea and the U.S. The Korean ads were taken from four issues of five popular Korean magazines: Thirty ads were taken at random from each the final Korean sample consisted of 600 different advertisements. The U.S. sample of advertisements was taken across five months' issues of seven magazines after abolishing replica; the U.S. sample consisted of 403 ads. Content analysis of 600 Korean magazine advertisements shows that emotional appeals predominate in headlines, but rational appeals are more common overall and in the illustrations. Compared to results from 403 U.S. advertisements, Korean magazine advertising uses more emotional appeals. As a result, emotional appeals seemed more common than rational appeals in headlines but Korean magazine ads exercised greater use of rational appeals in totality. Korean illustrations have used more emotional appeals than are found in U.S. advertising, and mixed appeals were also common. Where, Korea used emotion more in ads for non-durables and the U.S. emphasized emotion in ads for services.

Advertising as a form of persuasive discourse is heavily loaded with persuasive appeals. According to Kotler \& Keller, this advertising "aims to create liking, preference, conviction, and purchase of a product or service. Some persuasive advertising uses comparative advertising, which makes an explicit comparison of the attributes of two or more brands" (2009, p. 505). Greek philosopher Aristotle has categorized the persuasive appeals as ethos, pathos, and logos. These Greek words are simply understood in modern English as ethics, emotions and reasons respectively. Aristotle has described these concepts in his book Rhetoric and the picture of the useful reasoning that the Rhetoric tenders is reasoning as control, or faculty, and we have to wonder the relation which could have to reasoning as scholar asset (Garver, 1994).

\section{Ethos- An Appeal to Credibility}

When we discuss about the persuasive nature of advertisement, we should never forget about the significant role of ethos. Ethos is eternity based on the truthfulness of presenter. It always appeals to a clout, 
sincerity and trustworthiness. "Ethos emphasizes the speaker's credibility and trustworthiness" (Samuel-Azran, Yarchi, \& Wolfsfeld, 2015, p.154-55). So, which is right for a good mediator should also be right for a fine deed (Garver, 1994). It increases the reliability and supports the decision making process. As a result, the audience can identify right and wrong about the subject presented there. Advertising should always be guided by ethics. The ethos of promotion has view to that extent the advertising behavior, judgment and performance must have a set of ethical principles of high-quality behavior (Danciu, 2014).

Law and enforcement of law sometimes become insufficient to guide human action and that lacking creates space for ethics. Ethics generates a kind of belief on the trustworthiness of the speaker and the audience is motivated to follow the idea delivered by him with credible effects. It is politically understood that the purpose of advert is wholly ethical and comparatively free from semantic trouble (Boulton, 1968). To achieve the persuasion, ethics establishes the good trustworthy characters and it is always affected by the reputation of speaker as well as moral principles followed by the characters. So it is a moral philosophy too. In the marketing ethics is a tremendously fundamental feature for which status, trustworthiness and achievement thrive on (Singh, 2014).

\section{Pathos- An Appeal to Emotion}

Advertisements are moreover driven by emotion as well. It is a call to the audiences' sentiment with compassion and empathy. For Garver (1994), these emotions are not uncooked and normal human emotions, but the emotions of people and motivate to feel is vital here rather than reading and listening. It touches a nerve full of feelings and moves consumers to do intended action. Nicolini, Cassia, \& Bellotto identified that "Emotional appeals generate positive or negative feelings that the consumer will associate with the advertising message" (2017, p. 264). It is used by advertiser relatively to the value of audience. Makers of the adverts create those types of advertisement which bring emotional connection with consumer. Consequently the consumer is more likely to connect with advertisements of those brands which have emotional and rational principles and information (Rizwan, Pirzada, Sohail, Nadeem, \& Murid, 2013). Emotional appeal captures the attention of consumer to products and services. It generates psychological attraction relating to natural happening and the reality of life and Action. Advertising looks for entire consumers into acquiring definite goods and services. It is always appealing to emotions and common sensibilities (Bolatito, 2012).

The prime aim of this advertisement is to extend their market. To achieve this goal emotionally, the language is be keenly designed to touch the emotions of consumers. It is very effective for getting people's attention. Color also significantly plays its role in advert carrying emotion, information and meaning to manipulate the consumers to production. Since the late 1800's scholars have been revising the ways that can affect a person mentally and emotionally (Hayko, 2010). So in this modern era of business, maximum amount of capital is invested in form of advertising in different media.

\section{Logos- An Appeal to Reason}

With the degree of intensity of ethics and emotions, logic encourages audience to think critically about what is presented there. It directly appeals to our intellect. In Encyclopedia of Rhetoric, Sloane (2001) however logos were observed as massively influential in experience and object as well. So, it is always supported by information, figures, facts and statistics. "Logos refers to logic based appeals often using facts and figures" (Samuel-Azran, Yarchi, \& Wolfsfeld, 2015, p. 154). It is scientific approach and it increases 
ethics of the presented subject matter. Logic is used to differentiate one product and service from other too. The rational faculty is used by receivers and makers of the advertising to differentiate competitor's products (Rizwan, Pirzada, Sohail, Nadeem \& Murid, 2013). The Rational appeal guides consumer with skill to select the good option avoiding another unnecessary one. One has to be so watchful while dealing with it that it can be confusing and misleading sometime. It is also understood as drug which has positive and negative consequences.

The Logos gives the comprehensive reasons. In logical appeal, fact, data and information are presented in advertisement in consistent manner. It, using logos, gives consumers the proof about how the product works. The logos of an advertisement can be the direct facts about the products and services. Logical appeal is very straightforward and drags audience to think about the services and products. Advertising agencies should be aware while producing the resources for influencing other and responsible for signing up methodical and logical ideas that would be organized in for hunting the advertising objectives (Coker \& One, 2012). By means of such persuasive appeals, the advertisers fulfill their major goal to persuade the consumer to purchase. Sometime in the name of the awareness, they indirectly manipulate the psyche and way of thinking.

While transferring the meaning in the communication process, these three appeals work simultaneously in advertising. Any appeal here as a component of this trinity adds some strength to other appeals, too.

At past also, during the Second World War many government agencies were busy to analyze the contents of mass communication to detect propaganda of their opponents and design parallel propaganda to counter them using such Aristotelian appeals. Until the end of the Second World War, this method was widely used in the study of texts from journalism, political speeches, and propaganda among other applications. Subsequently, the methods were taken up by other field including psychology, sociology, anthropology, history, and linguistics to move other to their desired direction (Krippendorff, 2012).

\section{Methodology}

This study is chiefly based on the descriptive research design. Aristotle in Rhetoric had offered the three modes of persuasive appeals: ethos, pathos and logos. Based on this trinity, the present study discusses the role of these three appeals in advertising behavior, especially in newspaper. How advertisement developers take advantage of this trinity to influence the behavior of consumers to use their products and services is the major concern of this study. Basically, as secondary data, nine representative color print adverts from two English newspapers of Nepal, The Himalayan Times and Republica of 15 and 16 February 2017 are conveniently selected and dominant contents of these advertizing are further interpreted here with the references of ethos, logos and pathos which individually or collectively manipulate the consumer behavior.

These selected samples have been interpreted using content analysis. Hence content analysis is the process of generating meaning completing the course from text to context. Along with the process of investigation, Krippendorff (2012) argues that content analysis is a method used by researchers to identify, classify, and categorize trends within the content of communication; whether by text, speech, images, or by video. In content analysis, a minute study of the components of communication is conducted ranging from content to context as well. It studies summarizes and interprets the body of communication. It is developed by communication specialists to study their dilemmas which is used in history, literature 
law, anthropology marketing, and commercial matters as well. More specifically, Montabon, Sroufe, \& Narasimhan identify that "content analysis as a means of gathering data in operations management quite rare" (2006 p. 1001-2) but in other business disciplines, it has been firmly established as a major methodological tool. Among the fields of management, most notably, in the field of marketing it is used to assess various forms of text data, such as advertisements (Howard \& Kerin, 2006).

\section{Conceptual Framework}

The study discusses the usefulness of ethical, emotional and logical appeals which are adopted by newspaper advertising. Advertising, being a mass promotion strategy of the particular products or services, consists of credible, emotional and logical information and ideas to be communicated to make the content effective. Customers simply recognize these messages, but their capability to interpret and give opinion to the advertisers depends on their level of participation, attention, character sensitivity and social values, with a variety of other issues (Mogaji, 2016).Parallel to this advertising, customer needs basic literacy related to rhetoric as well. So the newspaper advertising behavior should discuss these appeals as shown in the framework.

\section{Independent Variables Dependent Variable}

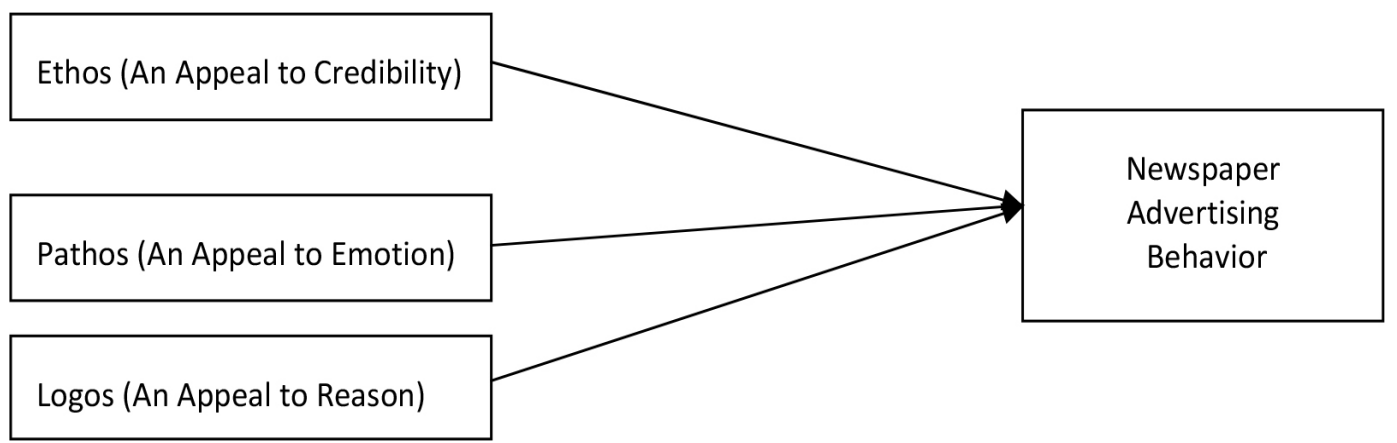

\section{Data Analysis and Interpretation}

These conveniently selected samples are deeply observed and briefly interpreted relating to ethos, pathos and logos. This process foregrounds how these appeals are working to stimulate costumer. Language, images and colors are also considered here.

\section{Do these cause sensation?}

To promote Sensodyne Toothpaste, an image of a doctor is used here with white coat including identity. The argument made by doctor creates utmost value in society. The advertiser seems to have the idea that health care professionals like doctors obtain higher degree of credibility and it contributes for ethos. The information in the advertisement, given by a dentist becomes logical. As an expert on the subject, the voice of this advertising psychologically motivates to follow. The rhetorical question- 'Do these cause a sensation in your teeth?' as headline enforces consumer to response positively that ice-cream, tea and cold drinks really cause sensation. The rhetorical question plays emotional game with audience. The advertiser claims it as its 'Number-1'product with a reference to a research conducted in India to earn credibility. There is little fallacy in the argument related to research because it lacks evidences. Excluding this criticism, this advertising has incorporated all three appeals. 


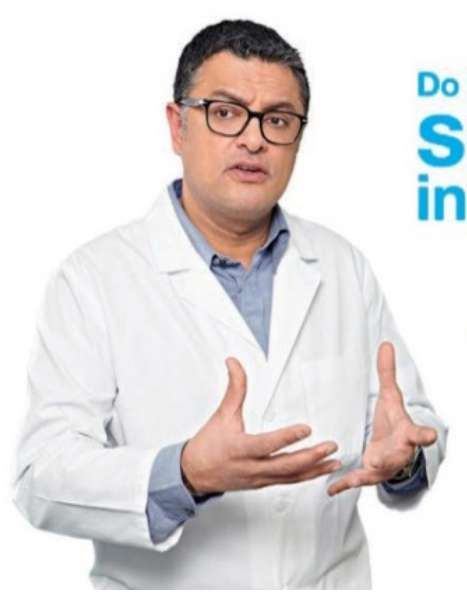

\section{Do these cansea sensation?
in your teeth}

"I recommend Sensodyne"

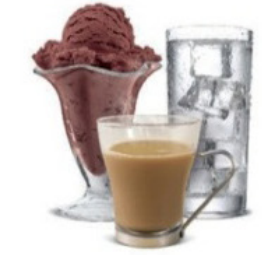

\section{Dr. Satbir Golar,}

Dentist. Practising in the UK

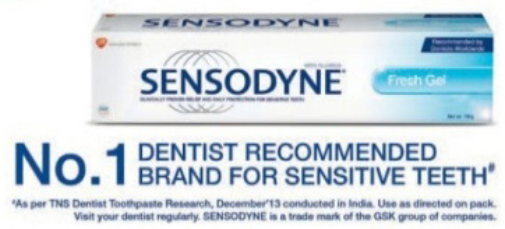

Fig. 1: Sensodyne

\section{Are you insured?}

Using rhetorical question- 'Are you insured?' the advertisement developed by Nepal Life Insurance Company tries to convince that it (insurance) really insures. The question makes this advert conversational. An image of a nuclear family is portrayed here and it has social, psychological and personal interpretations. This setting appeals to think for themselves as well as for next generation emotionally. The picture of the family indicates as a vehicle of responsibility and collective decision. Major features of policies are listed in points to communicate to consumers fairly. The one window service as claimed serves a motivation to buy policies which avoid unnecessary hurdles. Projecting a card, a lady assures hundred present bumper bonuses of the sum assured to make it reasonable but small letter approx at top confuses audiences. Psychologically, the previous rhetorical question, while reading between lines, tells that no one can be insured without insurance.

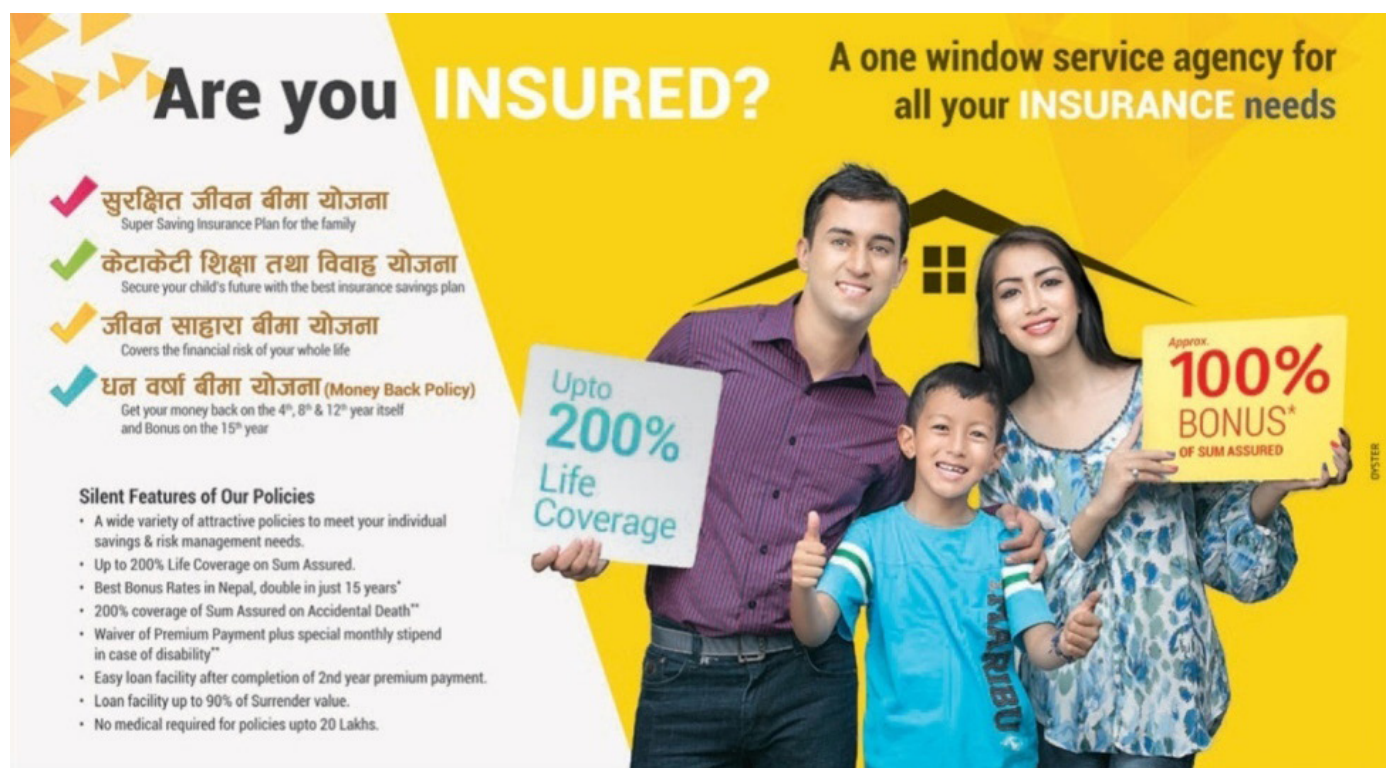

Fig.2: Nepal Life Insurance 


\section{Ncell- Internet for All}

This advertisement of Ncell has been published relating to admired social network- Facebook. Associating oneself with popular social site is a strategy of Ncell to be well-liked. Four young guys seem so excited to get such Facebook in Ncell at no cost. The alliterative words 'Free' and 'Facebook' are also contributing for music which simply captures the emotion of audience. The major slogan - 'Internet for all' sounds like fundamental right of people. The word 'free' deserves major attraction. It is simply designed targeting youth emotions who keep themselves busy in virtual communication.
With youth marketing strategies, catchy and lucrative features of Ncell are beautifully presented. Rich purple color text box has been used to relay information clearly indicating the brand color endorsed by the company to make the brand more easily recognizable and recalled to the customer besides showing 'Facebook' in its as usual trademark. Audiences could be little skeptical about the proposed service that even by paying people are failing to get better service, how can consumer get such services without paying single penny. The advertisement is also unspoken about the catch up links which are so vital in new-media.

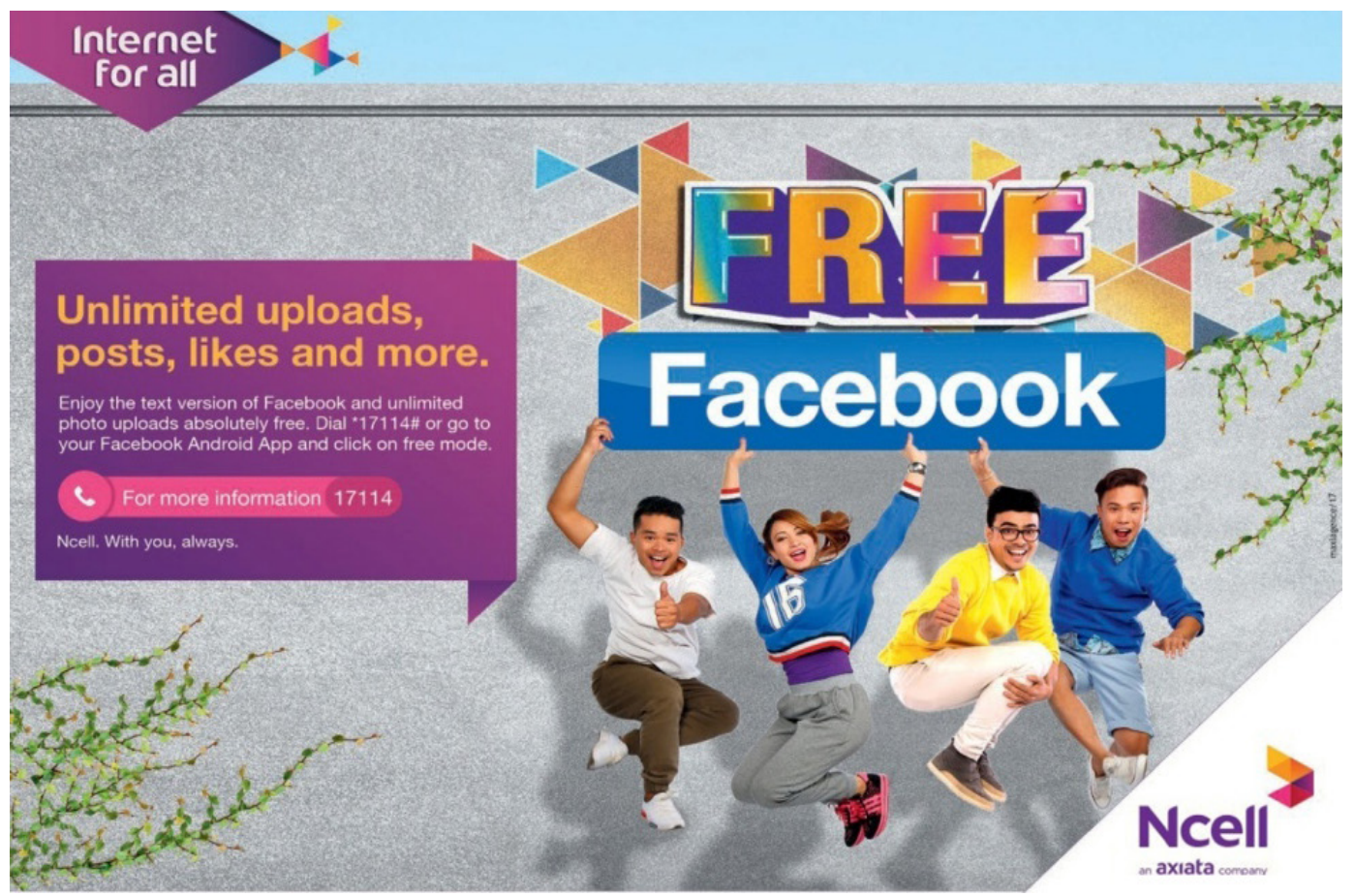

Fig.3: Ncell - Internet for all

\section{Mega 12- 12}

The commercial of Mega Bank clearly indicates the contemporary liquidity crisis faced by almost banks. Even 'A' class bank like Mega has to offer such mega interest rate. Sport and entertainment celebrities are used to promote the services as marketing strategies to provoke credibility, reliability and trustworthiness among consumers. The straight facts presented here make the ad more logical. Consumers remember the celebrities, and then they are encouraged to use services. The number 12 , with its brand colors, is repeated here and because of this, 
it sounds louder and bigger in number. It is an emotional game. A famous cricketer Paras Khadka and filmy actress Priyanka Karki are introduced here as celebrity endorsement to make the claim convincing. Exposing offer, Karki welcomes customers. In the same way, Khadka guides consumers to his mega interest rate. Code mixing is another noticeable linguistic feature to motivate audience. The expressive gesture is another positive feature to guide someone to this advert. Even in small space, the advertisement incorporated more information. But, there is also the extended space for persuasion because of the presence of celebrities and facts.

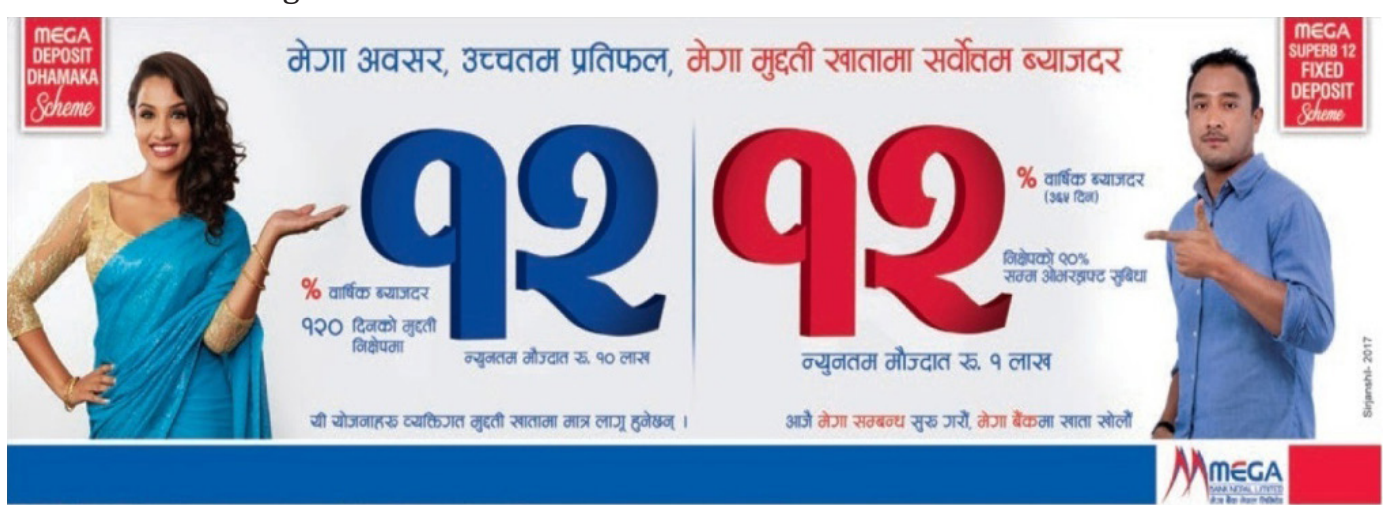

Fig.4: Mega Bank

\section{Really Real}

It is clearly noticeable in the juicy picture that the advertisement of Real Juice has exploited a popular form of sales promotion technique Buy Two and Get Something Free. The words 'free' and 'offer' make any purchaser excited and attentive to that. But, while thinking critically, a common consumer becomes skeptical and calculates that they are not getting something precious after buying two packs of Real. The word 'attractive' is used with freely offered glass with purchase of two packs of Real but in practical ground it is neither attractive nor costly. The background of the advert is really thirst quenching. The orange color is widened everywhere for the indication of freshness, happiness, positivity and intellect and makes the environment emotional. It is interpreted as passion too. The presence of the calm and confident lady in the ads, who is ready to drink a glass of juice, motivates any audience to drink it with her to recollect such confidence and calmness in his/her life. As celebrity endorsement, the Everester and actress Nisha Karki boldly presents herself in white shirt. This white short worn by her stands for purity. It appeals to credibility that white color is allied with medical field. The flavor of originality is also given by name itself linguistically. It is the matter of sentiment- 'What's in a name?'

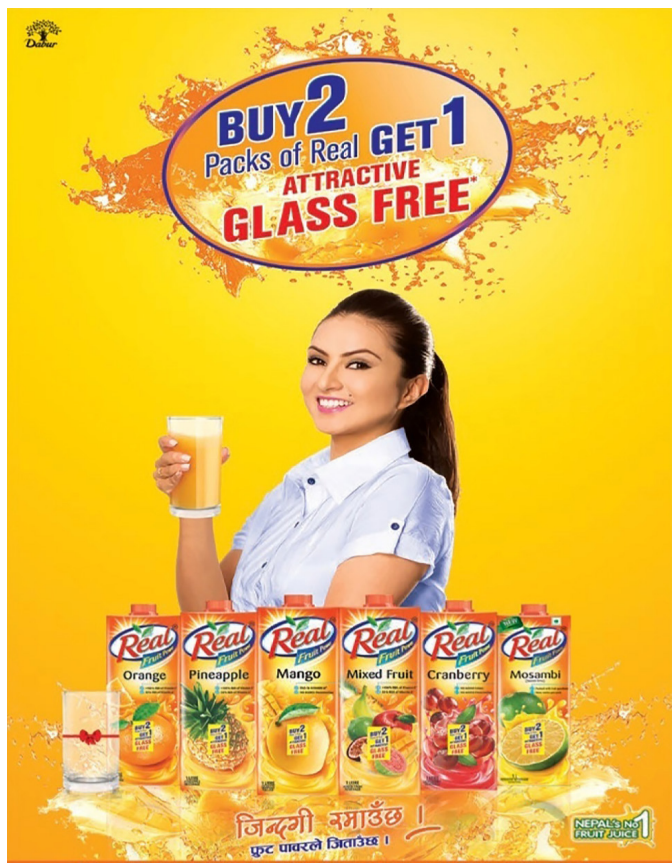

Fig. 5: Real Juice 


\section{Come Alive with Liril}

In this case, a sexy lady in glamorous costume is excitingly playing in blue water fall forgetting whole world. Here, she is exposed more than product itself. The soap- Liril is associated with beauty of her as well as the beauty of nature. In nature, she seems satisfied with it. This projected greenery and the word 'freshness' have connection. The beautiful image of the lady, evergreen environment and her glamorous outlook are working simultaneously to make any audience emotional and appeals to try it. Female audience dreams to be like her and male undergoes passionately about the strength of the products she uses. The advertising has used complex neuromarketing strategy that makes product more appealing psychologically using sexy environment. Advertiser seems aware about the phrase that 'sex sells'. Objectification and commodification of female body can be detected by critical audience which is pervasive here. This highly arousing red advertising technique could be the matter of taboo for the people of certain age and cultural group. Anyway, it is adequate to

\section{Beyond Imagination}

Can any product exist beyond human imagination? But such claim is made by Sama Printer in this advertising. To show logics, the advertisement comes Alone with the list of 35 services. Sama has also used the slogan- 'We print beyond imagination' as verbal branding to make costumers emotional. The colorful ball of single eye of unknown human is like the rich printing result of itself. It also seems as hawk eye which is always guided to its target. It is popularly said that eye is window to soul. Similarly this passionate eye could be the path to enter to the multiple features of it. We can perceive it as an eye contact to costumers as a symbol of confidence, too. The list of varieties makes the ad convincing. The attractive outlook of the advertise is enough to grab the attention of any viewers and enforces to ask- Does it really print beyond imagination? appeal sensation. The packaging of the soap as shown in the advertisement is of yellow color, generally indicating freshness. The advertiser is trying to associate the purity of water to the originality of product too.

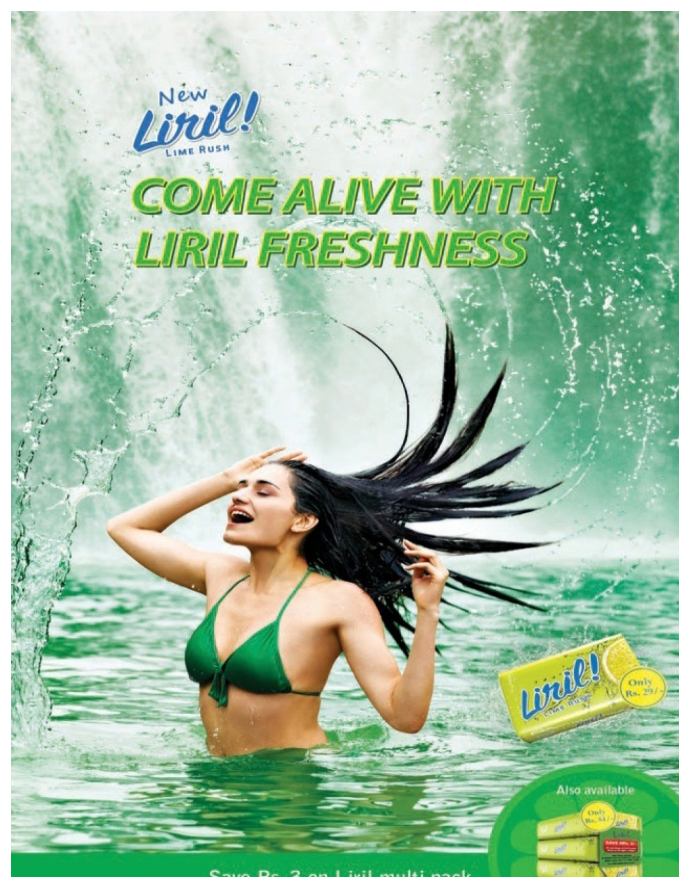

Fig.6: Liril

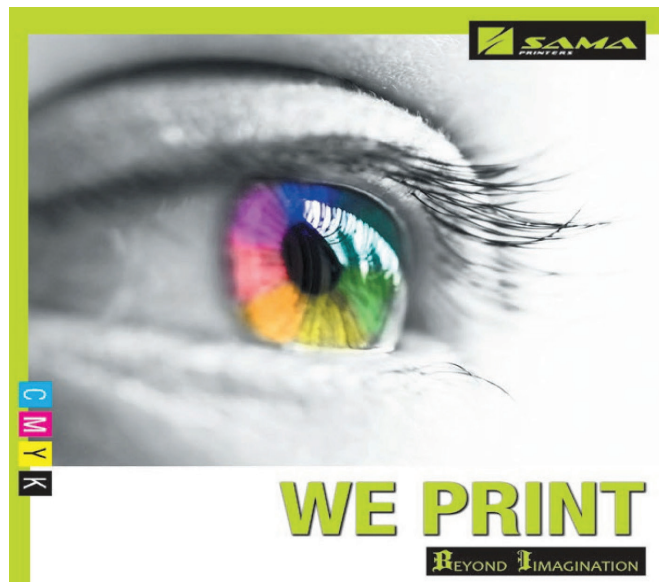

OUR SERVICES

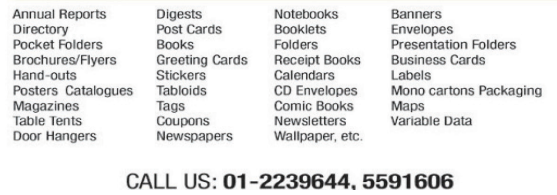

Fig. 7: Sama Printer 


\section{SAMSUNG Galaxy C- 9}

This commercial advert of Samsung Galaxy C9 Pro has used the sense of adventure invention and exploration distinctively touching the cognitive part of the customers logically. On the one hand, this adventurous picture is telling about the picture quality of Galaxy 9 Pro and on the other hand, it convinces that the life will be full of fun, adventure and action after being the user of it. It is difficult to catch the angle of the advert but it is original, catchy, thought provoking and emotional. The repetition of the word 'Big' stands for emphasis. The parallel structure of the phrases used to describe the features of the upcoming mobile phone is utilized to gain attention. It contributes for cohesion and arguments which become reasonable. Data related to screen, speed, camera and capacity also add much for logical reasoning. Call for pre-booking touches the sentiments of the consumers with the implied message that the product might not be available in market for a longer time.

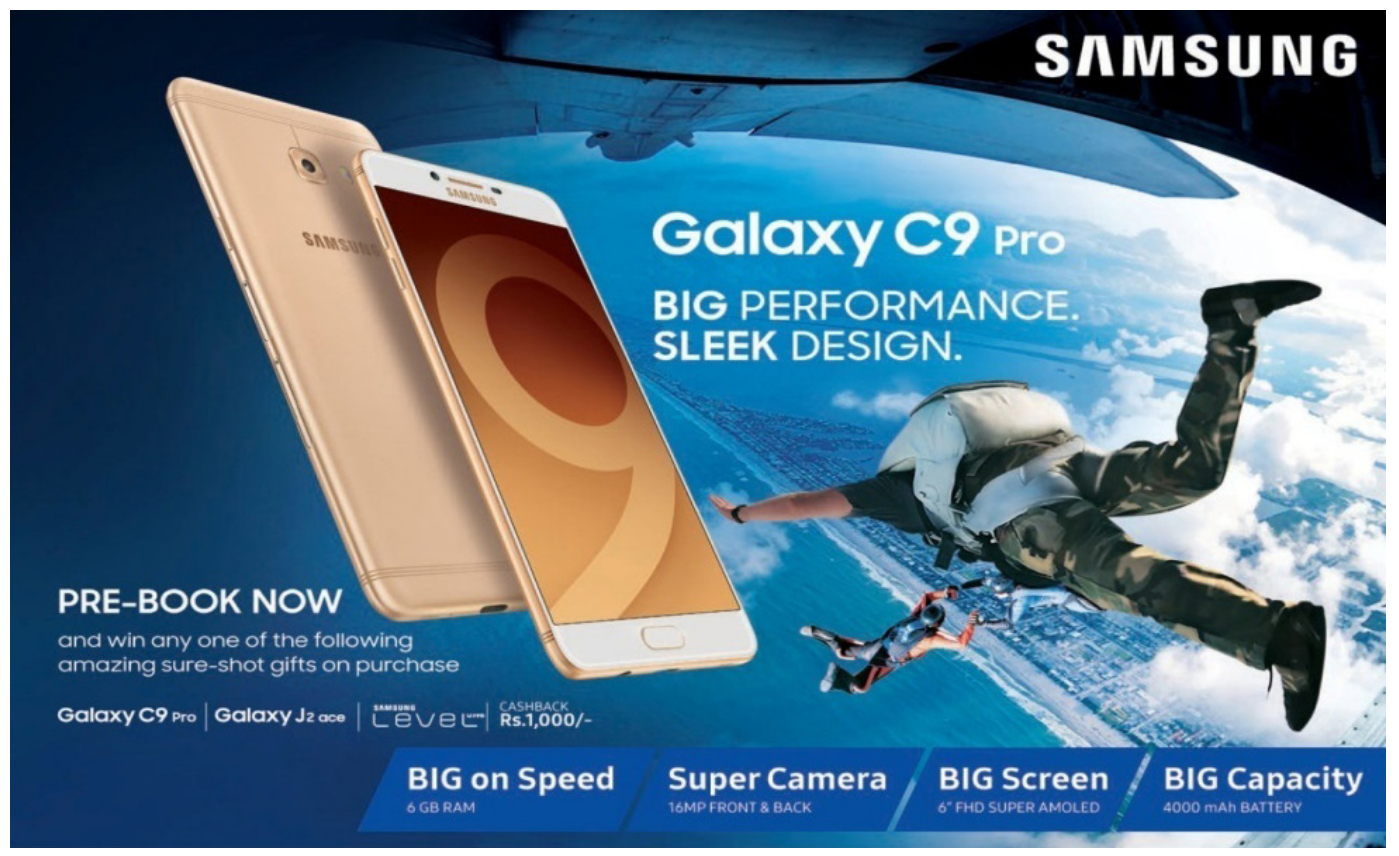

Fig.8: Samsung Galaxy

\section{Australian Education Expo -2017}

The advertising of Australian Educational Expo- 2017 in figure 9 is designed properly. It has incorporated maximum verbal information including logo, barcode and picture to make the message reliable. In the world of marketing the word 'Free' is one of the most powerful words and the word 'Free' is thoughtfully utilized to notify only the 'free entry' there in expo. They also claim 50\% discount in IELTS and TOEFL preparation classes but it does not declare the exact fee. It is emotional but failure to be logical in the absence of exact fee for the classes. Organizers are clearly mentioned. And, there is the provision of online registration as an outline of direct marketing. Appropriate descriptions and enough information make the advert fair and sincere to generate trustworthiness. The advertisement is highly informative but emotional and manipulative in the sense that it is also able to grab the attention of teenagers who always dream about abroad study. The advert deals intrinsically to magnetize the unemployed youth who is in search of opportunities. 


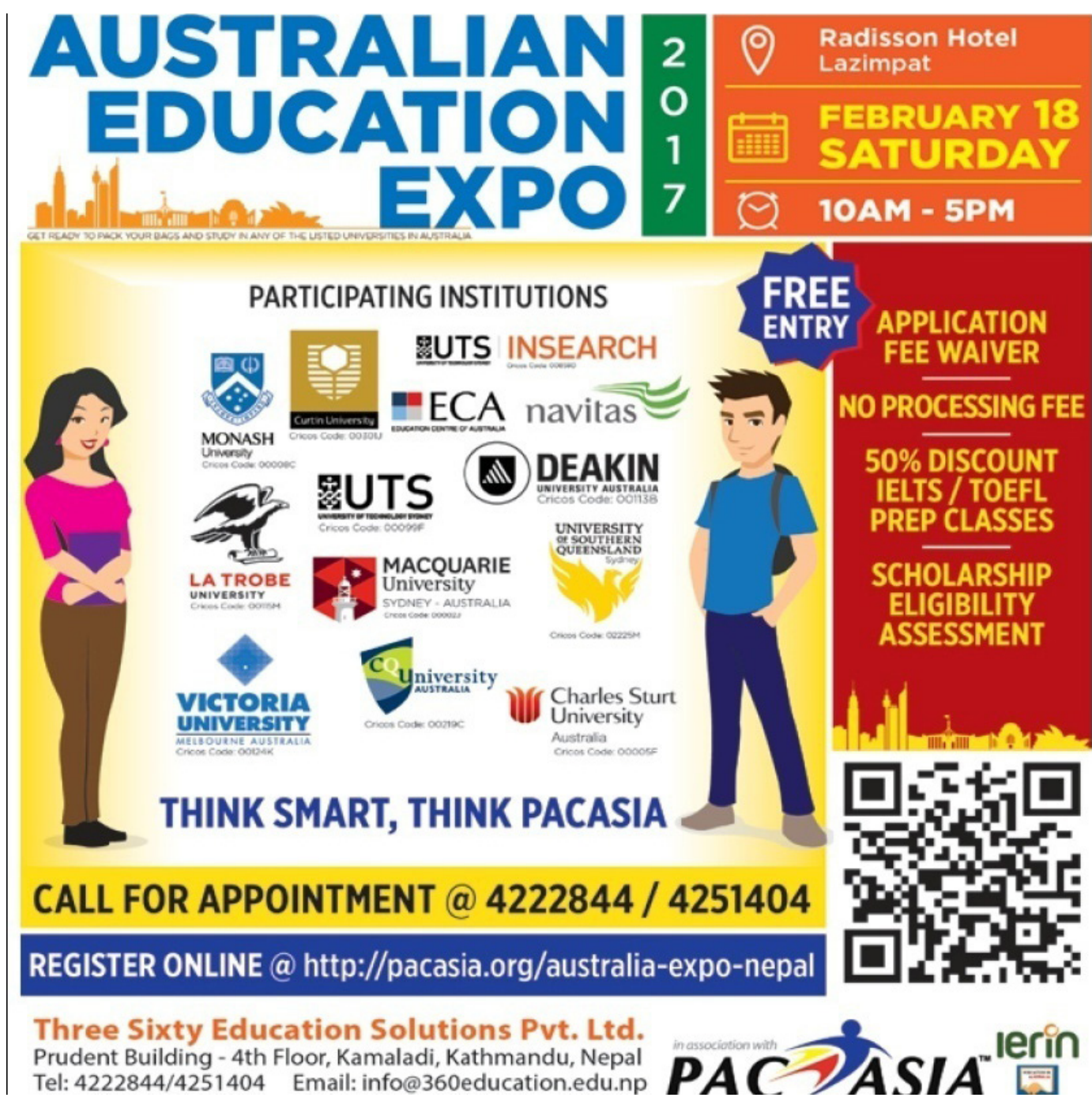

Fig.9: Australian Expo

\section{Conclusion}

The apparent motive of all advertisements is to transfer the seeming common concepts and goods into extremely desirable services and commodities. After the analysis of these advertisements, there is the revelation that no advertisement is designed apart from persuasive appeals completely. Almost all ads are so conscious to merge language, image and color according to their nature of product and service to play with the sentiment of the costumers keeping literate audience in mind. These ads are made by allocating enough space to think and rethink before interpretations. Popular but cheap marketing strategies like free offer, buy one get one free and discount are so common to draw the attention of the audience directly. Gorgeous and sexy bodies are exposed as complex neuromarketing strategy. The role of such sexy body seems successful to draw the attention of both male and female. Sex sells there. Celebrity endorsement and sexual appeals are highly practiced in different ads 
to motivate emotionally.

Hence expert from adequate fields are used to strengthen credibility and enhance reasoning. There is the total capitalization of beauty and knowledge of the deployed characters to construct the argument of business houses more authentic and credible. Rhetorical questions are also planned to drag the audience for critical thinking. Some symbolic pictures which are used in the different advertising also call consumer to contemplate upon the concept used by them. The enchantment of youth towards virtual communication is addressed in the advertising in form of free offer and teenagers' fascination for abroad study is supported in the name of free entry as well as discounts. Sometime interpretation is being highly subjective when vague images are associated with ambiguous statements. Even among common trinity of ethos, pathos and logos, emotion is almost all-pervading and the same sensation is also contributing for ethos and logos. Some advertisements are being fallacious in the deficiency of valid argumentation process and failure to guide towards evidences. Though it seems rare, only the proper combination of ethos, pathos and logos is being successful among these advertisements.

\section{References}

Bolatito, O. (2012). Linkage between Persuasion Principles and Advertising. New Media and Mass Communication, 8, 7-12.

Boulton, M. (1968). The Anatomy of Language. Dunfermline, United Kingdom: Routledge and Kegan Paul PLC.

Coker, O., \& One, S. (2012). "Arts for AD Sake": Advertising Language as Literary Language in Selected Advertising Copy in Nigeria. The African Symposium: An online journal of the African Educational Research Network, 11-17.

Danciu, V. (2014). Manipulative Marketing: Persuasion and Manipulation of the concumer through advertising.
Theoretical and Applied Economics, 1934.

Garver, Eugene. Aristotle's Rhetoric: An Art of Character. Chicago: University of Chicago Press, 1994.

Hayko, G. (2010). Effects of advertising on society: A literary review. Hohonu, 8 , 79-82.

Howard, D.J. \& Kerin, RA (2006). Broadening the scope of reference price advertising research: A field study of consumer shopping involvement. J Marketing 70: 185-204

Jeon, W., Franke, G. R., Huhmann, B. A., \& Phelps, J. (1999). Appeals in Korean magazine advertising: A content analysis and cross-cultural comparison. Asia Pacific Journal of Management, 16(2), 249-258.

English, K., Sweetser, K. D., \& Ancu, M. (2011). YouTube-ification of political talk: An examination of persuasion appeals in viral video. American Behavioral Scientist, 55(6), 733-748.

Kanner, A. D., \& Soule, R. G. (2004). Globalization, corporate culture, and freedom. American Psychological Association , 49-67.

Krippendorff, K. (2012). Content Analysis: An Introduction to Its Methodology ( ${ }^{\text {rd }}$ Ed.) Thousand Oaks, CA: Sage.

Kotler, P. \& Keller, K. L. (2012). Marketing Management. New Jersey, US: Pearson Education.

Nicolini, V., Cassia, F., \& Bellotto, M. (2017). Children perceptions of emotional and rational appeals in social advertisements. Young Consumers, 18(3), 261-277.

Mogaji,E.(2016). Emotional appeals in UK banks' print advertisement.

Montabon, F.; Sroufe, R.; Narasimhan, R. (2006). An examination of corporate reporting, environmental management practices and firm performance. JOpns Mngt 25: 998-1014.

Pollay, R. W. (1986). The distorted Mirror: Reflection on the Unintended consequences of Advertising . Journal of Marketing , 18-36. 
Rizwan, M., Pirzada, S., Sohail, A., Nadeem, M., and Murid, W. (2013). The Role of Advertising Appeals, Role of Celebrity and Expert in T.V Advertising Attitude. IOSR Journal of Business and Management , 52-57.

Samuel-Azran, T., Yarchi, M.,\& Wolfsfeld, G. (2015). Aristotelian Rhetoric and Facebook Success in Israel's 2013 Election Campaign. Online Information Review, 39(2), 149-162.
Singh. M. (2014). Ethical Issues and Principles Related to Advertising. Abhinav-National Monthly Refereed Journal of Research in Commerce \& Management (Online ISSN 2277-1166), 3(6), 100-108.

Slade, C. (2002). Reasons to buy: The logic of advertisements. Argumentation, 16(2), 157-178.

Sloane, T. O. (Ed.). (2001). Encyclopedia of Rhetoric, New York: Oxford University Press. 